\title{
An Economic Impact of Drip Irrigation in Vegetable Production in Scarcity Region of Western Maharashtra
}

\author{
M. N. Waghmare*, Y. C. Sale and P. N. Shendage \\ College of Agriculture, Pune, India \\ *Corresponding author
}

Keywords

Drip irrigation,

Water scarcity,

Economic benefits

Article Info

Accepted:

20 June 2020

Available Online:

10 July 2020

\begin{abstract}
A B S T R A C T
Considering the fast decline of irrigation potential and increased demand for water from different sectors, many initiatives have been introduced to conserve the scarce water resources in India. One of the methods introduced to save water consumption in agriculture was drip method of irrigation (DMI). Several studies have assessed the technical and economic feasibility of drip irrigation in a number of crops and have proven its potential to save water and energy, and to increase crop yields. However, only a few studies have assessed its techno-economic potential in vegetable crops. In this paper, using survey data from scarcity region of western Maharashtra, we assess its potential in brinjal, a widely cultivated and consumed vegetable in the country. The findings indicate that besides savings in water $(38 \%)$ and electricity $(547 \mathrm{kwh} / \mathrm{acre})$, the drip irrigation reduces use of other inputs, e.g. fertilizers (29\%), and enhances crop yield by 52 per cent\%. The profitability of brinjal cultivating farmers under drip method of irrigation is about 72 per cent more than the conventional method of irrigation.Both NPV and BCR, estimated using the discounted cash flow analysis, show that the drip investment in brinjal cultivation is economically viable even without subsidy.
\end{abstract}

\section{Introduction}

Irrigation water is a critical input for agriculture. Therefore, it is often considered as an engine of agricultural growth. Many research studies have underlined that irrigation water plays a critical role for sustained reduction of rural poverty. But, the state of water scenario is very precarious in India today. While the available potential of water for future use has been declining at a faster rate, the demand for water has been increasing at an alarming rate due to its ever increasing demand for the energy, industry and domestic purposes in India (CWC, 2010; FICCI, 2013). Despite this, the irrigation water in India is predominantly applied through the conventional flood method of irrigation where the efficiency of water is very low ranging from 35-40 per cent because of huge conveyance and distribution losses (INCID, 1994; 2001; GoI, 2004, Narayanamoorthy, 2005). Several studies on the application of drip method of irrigation (DMI) in high-value crops (e.g., grapes, banana, sugarcane and cotton) provide strong evidence of its techno-economic feasibility (Narayanamoorthy 1997, 2004a; Namara et 
al., 2005). But, there is hardly any study that provides such an evidence on its application in vegetable crops. The main objective of this paper is to study economic impact of the application of drip method of irrigation in vegetable cultivation focusing on brinjal, a widely grown and consumed crop in Maharashtra. In India, brinjal is grown on 0.73 million hectares, equalling $7.12 \%$ of the total area under vegetable crops, next only to China. Its yield, however, is low (17.5 t/ha), just half of that in China. In Maharashtra the total Area of Brinjal is 23 ' 000 hectares, Production is 430 '000 MT and Productivity is $19.12 \mathrm{MT} / \mathrm{HA}$. One of the main reasons for low yield is inadequate and erratic supply of irrigation water. Vegetables are fleshy and sensitive to water stress, and therefore require irrigation at regular intervals and at their critical growth stages. The water stress may delay maturity of the crop and result in poor quality and low yield as well. However, owing to acute water scarcity (Seckler et al., 1999; CWC 2010), farmers are unable to provide irrigation at a regular interval for crops. The drip method of irrigation has the potential to completely eliminate water stress for crops even under severe water scarcity conditions. Through a network of pipes and emitters, the water is delivered directly in the root zone. This method is entirely different from the conventional method, where water is supplied to the whole crop land. The excess supply of water through conventional method is a potential loss of water, and at times may adversely affect crop yield,

The evidence on the benefits of DMI in vegetable cultivation, especially brinjal is scarce. Some experimental studies show that DMI in brinjal increases crop yield in the range of 20 to 60per cent besides saving water by 40 to 60 per cent (Biswas 2010; Chauhan et al., 2013). The evidence from controlled experimentations although prove the technical feasibility of DMI, but not its economic feasibility in farmers' conditions as the establishment of DMI requires fixed capital investment that needs to be factored while assessing costs and benefits associated with it. In view of this, using data collected from sample farmers, we generate operation specific estimates of savings in costs and improvement in crop yield and the associated net returns. Further, using these parameters, we assess economic viability of DMI to provide feedback to policymakers for informed decisions for financial support to DMI. Since studies seldom are available on the economics of drip method of irrigation especially on short duration crops like vegetables, an attempt has been made in this study to fill this gap. The major objectives of the study include to study the operation-wise cost of cultivation of drip and non-drip irrigated brinjal crop. And also to study the impact of drip method of irrigation on profitability of brinjal crop. To find out the economic viability of drip investment in brinjal crop cultivation.

\section{Materials and Methods}

The study is based on data collected from a sample of farmers cultivating brinjal with drip and flood methods of irrigation in Pune and Satara district. These districts are located in the scarcity region of western Maharashtra, and was purposively selected because of acute water scarcity there. One tehsil falling under scarcity zone from each district was selected. The agriculture in the districts is raindependent with well as one of the main sources of irrigation. The normal rainfall in the region is $750 \mathrm{~mm}$, but annual rainfall fluctuates widely. For this study, we have selected a total of 60brinjal farmers; 30 adopters of DMI and 30 non-adopters of DMI. The adopters were selected randomly from the list obtained from the State Agriculture Department. The non-adopters were selected purposively; only those farmers 
were selected whose fields were nearer to the fields of adopters of DMI. The relevant data were collected from the sample farmers for the year 2016-17.

Partial budgeting technique was used to compare technical and financial parameters associated with brinjal cultivation with and without DMI. Since drip irrigation involves capital investment, we assess its economic viability estimating, net present worth (NPW) and benefit-cost ratio (BCR) following discounted cash flow technique (Gittinger 1984). The NPW is the difference between the sum of the present value of benefits and the costs accrued during the life period of the drip set. As per NPW criterion, the DMI is economically viable if the present value of benefits is greater than the present value of costs. If the value of $\mathrm{BCR}$ is greater than unity, the investment can be considered economically viable. From cross-sectional data, it is not possible to determine the actual cash flows for the entire life span of drip set. Therefore, we estimate cash inflows and cash outflows on the following assumptions.

- The life period of the drip-set is five years (INCID, 1994). But, based on the experience of adopters of DMI a drip set can last up to 10 years, hence we also estimate these assuming 10 years life span.

The discount rate or the opportunity cost of capital is assumed to be 10 per cent.

\section{Results and Discussion}

Economics of brinjal cultivation under DMI versus FMI.

\section{Water and electricity consumption}

The major advantage of drip method of irrigation is water saving. As water is supplied directly to the root zone of the crop through DMI, considerable amount of water losses occurring due to conveyance, distribution and application are reduced at the field level. Under field conditions, it is difficult to arrive at precise estimates of water used for irrigation because of variation in the horse power (HP) of the pump sets used to lift water, groundwater depth, capacity and quality of water delivery pipes, conveyance distance, field terrain, etc. We, therefore, compute quantum of water in terms of horse power hours, multiplying HP of the pump-set by the number of hours used to pump water.

Table 1 compares water use in DMI versus FMI. Though the numbers of irrigations are much larger with DMI, the duration of hours used for each irrigation is much less; 1.05 hours/acre compared to 4.95 hours/ acre with FMI. As a result, the total water used for dripirrigated crop is $1173 \mathrm{HP}$ hours/acre as against 1902 HP hours/acre in FMI. This shows, drip irrigation saves about 38 per cent of the water. Less use of water means less consumption of electricity to pump out the water from wells. In this study, we have estimated electricity consumption assuming that a pumpset of one HP requires $0.750 \mathrm{kWh}$ of energy per hour. Accordingly, the electricity consumption with DMI is estimated880 $\mathrm{kWh} /$ acre as against 1427 $\mathrm{kWh}$ /acre with FMI, saving of about 38 per cent.

\section{Cost of cultivation}

Water saving and higher crop yields are often highlighted as the two major advantages of drip method of irrigation. DMI reduces the cost associated with operations like irrigation, weeding, ploughing and preparatory works. To study the impact of DMI on various operational costs of cultivation, we have compared cost associated with these operations under drip-irrigated brinjal with flood-irrigated brinjal. 
Table 2 shows operation-wise cost of cultivation under DMI and FMI systems. As expected, DMI saves considerable cost of irrigation (60\%). Since DMI supplies water directly to the root zone that does not allow weeds to grow, there are enormous savings in the costs towards weeding and inter-culture (70\%). Likewise, relatively fewer requirements of ploughing and other preparatory operations reduce cost of field preparation. On the whole, DMI reduces total cost of cultivation by 19 percent.

\section{Productivity}

Table 3 shows that yield of brinjal cultivated with DMI (187.25qtl/acre) is 1.5 times more over that obtained with FMI. Farmers have opined four main reasons for higher yield with DMI. First, by supplying right quantity of water at right time, DMI reduces moisture stress for the crop leading to better plant growth and thereby better flowering and less pre-mature dropping of flowers and fruits. Second, by restricting supply of water to root zone, DMI avoids water flow to other zones and hence less infestation of weeds. Third, supply of water at regular intervals allows the crop to absorb plant nutrients avoiding their loss through leaching and evaporation. Fourth, better plant growth allows extendable harvest of fruits. Besides higher yield, DMI enhances productivity of water as well as of energy, which are reported in table 3.

\section{Profits}

The reduction in cost and yield advantage clearly establishes that DMI is technically and economically superior over FMI.

Table 4 presents gross and net returns from brinjal cultivation. Gross returns are obtained multiplying yield with the prices realized by the framers and, the net returns are estimated deducting the variable cost of cultivation from gross returns.

The net returns (farm business income) are estimated Rs. 2,39,485 per acre of brinjal with DMI as compared to Rs. 1,39,318 with FMI. It indicates that, the brinjal cultivation using drip irrigation generates 72 per cent more of profit over the conventional method of irrigation.

\section{Economic viability of investment in drip irrigation}

Adoption of drip method of irrigation in the field involves certain amount of fixed investment, which varies from crop to crop. One must study whether the investment is economically viable to the farmers cultivating brinjal. Although, farm business income from cultivation of brinjal using DMI is significantly higher as compared to conventional irrigation method, this cannot be treated as the effective (real) profit as we have not accounted for the cost, depreciation and interest on capital investment associated with installation of drip system. Importantly, the longevity of drip system is an important factor in estimation of net present value. DMI is capital-intensive technique. Therefore, it is imperative to assess the economic viability of investment in drip irrigation.

The average capital cost of drip set is estimated Rs. 41,750/acre without subsidy. Most states including Maharashtra are providing almost $50 \%$ of the capital cost as subsidy either through a state sponsored scheme or centrally sponsored scheme to encourage the adoption of drip irrigation in different crops. The NPW and the BCR have been estimated with and without subsidy. 
Table.1 Water and electricity consumption in drip and flood irrigated brinjal

\begin{tabular}{|l|c|c|c|c|}
\hline \multicolumn{1}{|c|}{ Particulars } & & & \multicolumn{2}{c|}{ Change over FMI } \\
\hline Pump set HP & DMI & FMI & Absolute & Percent \\
\hline Number of irrigation/acre & 5.25 & 5.1 & --- & -- \\
\hline Hours required per irrigation/acre & 212.8 & 75.35 & 137.45 & 182.42 \\
\hline HP hours of water used/acre & 1.05 & 4.95 & -3.9 & -78.79 \\
\hline Electricity consumption (kWh/acre) & 1173.06 & 1902.21 & -729.15 & -38.33 \\
\hline
\end{tabular}

Table.2 Operation wise cost of cultivation of drip and flood irrigated brinjal(Rs/acre)

\begin{tabular}{|l|c|c|c|c|}
\hline \multicolumn{1}{|c|}{ Particulars } & & & \multicolumn{2}{c|}{ Change over FMI } \\
\cline { 4 - 5 } \multicolumn{1}{c|}{ Preparatory works } & DMI & FMI & Absolute & Percent \\
\hline Seed and sowing & 3045 & 4610 & -1565 & -33.95 \\
\hline Fertilizer & 795 & 880 & -85 & -9.66 \\
\hline Farm yard manures (FYM) & 11485 & 16115 & -4630 & -28.73 \\
\hline Pesticides & 2730 & 2975 & -245 & -8.24 \\
\hline Weeding\&Interculturing & 14815 & 14995 & -180 & -1.20 \\
\hline Irrigation & 2588 & 8810 & -6222 & -70.62 \\
\hline Harvesting & 2650 & 6730 & -4080 & -60.62 \\
\hline Transport and marketing & 12940 & 11015 & 1925 & 17.48 \\
\hline Others & 8485 & 8390 & 95 & 1.13 \\
\hline Total cost & 2132 & 1992 & 140 & 7.03 \\
\hline
\end{tabular}

Table.3 Crop yield and resource productivity

\begin{tabular}{|l|c|c|c|c|}
\hline \multicolumn{1}{|c|}{ Particulars } & & & \multicolumn{2}{c|}{ Change over FMI } \\
\hline Crop yield (qtl/acre) & DMI & FMI & Absolute & Percent \\
\hline Cost of production (Rs/qt) & 187.25 & 122.95 & 64.30 & 52.30 \\
\hline Water productivity (kg/HP hr of water) & 329.32 & 622.30 & -292.98 & -47.08 \\
\hline Electricity productivity (kg/kWh) & 15.96 & 6.44 & 9.52 & 147.83 \\
\hline
\end{tabular}

Table.4 Profit from brinjal cultivation with and without DMI (Rs/acre)

\begin{tabular}{|l|c|c|c|c|}
\hline \multicolumn{1}{|c|}{ Particulars } & & & \multicolumn{2}{c|}{ Change over FMI } \\
\cline { 4 - 5 } & DMI & FMI & Absolute & Percent \\
\hline Gross cost of cultivation & 61665 & 76512 & -14847 & -19.40 \\
\hline Gross value of production & 301150 & 215830 & 85320 & 39.53 \\
\hline Profit (farm business income) & 239485 & 139318 & 100167 & 71.90 \\
\hline Capital cost of DMI (without subsidy) & 41750 & -- & -- & -- \\
\hline Subsidy for DMI & 17535 & -- & -- & -- \\
\hline Capital cost of DMI (with subsidy) & 24215 & -- & -- & -- \\
\hline
\end{tabular}


Table.5 NPW and BCR for drip irrigated brinjal

\begin{tabular}{|l|c|c|c|}
\hline Subsidy category & Life (years) & $\begin{array}{c}\text { NPW @ 10\% } \\
\text { (Rs. in ‘000/acre) }\end{array}$ & BCR \\
\hline With subsidy & 5 & 895 & 4.60 \\
\hline & 10 & 1382 & 4.75 \\
\hline Without subsidy & 5 & 865 & 4.22 \\
\hline & 10 & 1352 & 4.35 \\
\hline
\end{tabular}

Table 5 presents the results of NPW and BCR. The NPW with subsidy is marginally higher than without subsidy. For example, the NPW at 10 per cent discount rate for a drip set with five years life is Rs. 8,65,248/acre without subsidy and Rs. 8,95,148/acre with subsidy. The benefit cost ratio is quite attractive; 4.22 to 4.35 without subsidy, and marginally higher with subsidy. NPW and BCR are sensitive to the life of drip system. The ideal life of a drip system is 5 years, but may go up to 10 years if maintained properly. The results presented in table 5 show that with increase in life of drip set the NPW increases significantly but with marginal increase in BCR. Vegetable prices are volatile. Prices often decline with increase in their arrival in the market. Brinjal is no exception.

In conclusion the drip method of irrigation is highly suitable for vegetable crops, which are mostly cultivated by small holders. The productivity difference between drip and flood irrigated brinjal is about 64 per cent higher than the same harvested using flood method of irrigation. Besides saving water and increasing productivity in absolute terms, DMI has also increased the water productivity and the electricity productivity. The farm business income (undiscounted profit) of the brinjal crop cultivated using DMI is also substantially higher (72 per cent) than that of the profit realised from the same crop cultivated with conventional flood method of irrigation. The study proves that DMI is economically viable and environmentally sound alternative of conventional method of flood irrigation. Although, evidence shows that drip investment is economically viable, the initial investment required for installing DMI is beyond the reach of small farmers. This calls for improving small farmers reach to financial institutions.

\section{References}

Biswas, B. C. (2010). Fertigation in high-tech agriculture: a success story of a lady farmer. Fertiliser Marketing News, 41(10), 4-8.

Chauhan, R. P. S., Yadav, B. S., \& Singh, R. B. (2013).Irrigation water and fertigation management in brinjal crop with drip irrigation. The Journal of Rural and Agricultural Research, 13(1), 53-56.

CWC.(2010). Water and related statistics. Central Water Commission, Ministry of Water Resources, Government of India, New Delhi.

FICCI. (2013). Sustainable agriculture: water management. Federation of Indian Chambers of Commerce and Industry, New Delhi.Gittinger, J. P. (1984). Economic analysis of agricultural projects (2nd edition). The Johns Hopkins University Press, London.

GOI.(2006). Indian agricultural statistics. Directorate of Economics and Statistics, Ministry of Agriculture, New Delhi.

INCID (1994), "Drip Irrigation in India," Indian National Committee on Irrigation and Drainage, New Delhi.

Narayanamoorthy, A. (1997). Economic 
viability of drip irrigation: an empirical analysis from Maharashtra. Indian Journal of Agricultural Economics, 52(4), 728- 739.

Narayanamoorthy, A. (2005). Efficiency of irrigation: a case of drip irrigation. Occasional paper no.45,

Department of Economic Analysis and Research, National Bank for Agriculture and Rural Development, Mumbai, India.

Namara, R. E., Upadhyay, B., \& Nagar, R. K. (2005). Adoption and impacts of microirrigation technologies: empirical results from selected localities of Maharashtra and Gujarat states of India. Research report no. 93, International Water Management Institute, Colombo, Sri
Lanka.

NCPA.(1990). Status, potential and approach for adoption of drip and sprinkler irrigation systems.National Committee on the Use of Plastics in Agriculture, Pune, India.

NHB. (2014). Indian horticulture data base 2014. National Horticulture Board (NHB), Ministry of Agriculture, Government of India, Gurgaon, India.

Seckler, D., Amarasinghe, U., Molden, D., Silva, R. de.,\& Barker, R. (1998). World water demand and supply, 1990 to 2025 : scenarios and Issues. Research report no. 19 ,

\section{How to cite this article:}

Waghmare, M. N., Y. C. Sale and Shendage, P. N. 2020. An Economic Impact of Drip Irrigation in Vegetable Production in Scarcity Region of Western Maharashtra. Int.J.Curr.Microbiol.App.Sci. 9(07): 2259-2265. doi: https://doi.org/10.20546/ijcmas.2020.907.263 